\title{
Problematic search, slack search and institutional logic in corporate R\&D strategy: An empirical analysis of Taiwanese electronics firms
}

\author{
Lin-Hua Lu and Shin-Chieh Fang
}

\begin{abstract}
This study focuses on firms' search behavior with regard to corporate R\&D investment. Building on Cyert and March's (1963) behavioral theory of the firm, we develop specific hypotheses about how firms adjust their R\&D investment in response to performance discrepancies, and how this adjustment varies for two types of slack resources. Moreover, by utilizing institutional logic, we also hypothesized that the firms' search behaviors in response to performance feedback may differ between business-group affiliated and unaffiliated firms. Empirical evidence from panel data coving 274 Taiwanese electronics firms listed on the Taiwan Stock Exchange over the period 1999-2008 is consistent with our theoretical predictions. In particular, we find that firms will increase R\&D investment when they faced discrepancies in performance, but will decrease R\&D spending when close to bankruptcy. Moreover, our results show that unabsorbed and absorbed slack have different impacts, positively and negatively affecting R\&D investment, respectively. In addition, we find that both business group-affiliated and unaffiliated firms will increase $R \& D$ investment in response to negative performance feedback, but only business group-affiliated firms will increase R\&D activity when facing positive performance feedback. Furthermore, we also find that only business group-affiliated firms have a greater inclination to invest in $\mathrm{R} \& \mathrm{D}$ when there is unabsorbed slack. Our findings extend the claims of behavioral theory in newly industrialized economies, and identify the important factors that need to be considered in future studies.
\end{abstract}

Keywords: search behavior, aspiration level, organizational slack, business group

Received February 2013. Accepted February 2013

\section{INTRODUCTION}

Innovation strategy lies at the heart of all business activities of technology-based firms, and the innovation activities of a firm have a significant impact on its competitive advantages. High-tech firms are widely viewed as learning organizations that create knowledge (Rosenkopf \& Nerkar, 2001), and one common way for such companies to obtain new technology is to undertake higher levels of R\&D investment (Anderson \& Tushman, 1990).

However, $R \& D$ investment is associated with both high financial risk and uncertain results (Huang \& Jiang, 2012), because it requires the investment of significant amount of resources over a long period time. If a firm devotes too many resources to R\&D investment, it may enter a period of financial distress without any payoff over the short run. Conversely, if too few resources are focused

Business Administration and Institute of International Business, National Cheng Kung University, Tainan, Taiwan

Corresponding author: lydialu0816@gmail.com 
on $\mathrm{R} \& \mathrm{D}$, then a firm may miss valuable opportunities to develop new technology (Chen \& Miller, 2007). While prior studies have identified numerous factors that influence the level of $R \& D$ investment, such as a firm's potential profitability, technology opportunity and competitive situation (McGrath \& Nerkar, 2004), one stream of innovation research has applied the behavioral theory proposed in Cyert and March (1963) to explore how performance feedback influences a company's innovation strategy.

Performance feedback is a key mechanism that is used by decision makers to judge whether to increase or reduce innovation efforts (Argote \& Greve, 2007). However, previous empirical studies investigating the relationship between performance feedback and innovation strategy have produced conflicting results (Greve, 2003; Chen \& Miller, 2007). In the current study, we address this issue by focusing on an emerging economy, Taiwan, for the following reasons. First, many Taiwanese electronics companies have recently undergone a significant transition from original equipment manufacturer to original design manufacturing by establishing their own integrated circuits design centers, and now serve as key suppliers of materials and manufactured goods in the global electronics sector (Kang, Mahoney, \& Tan, 2009). Moreover, many of these firms now in invest R\&D to both improve their production abilities and establish their own brands (Mahmood \& Mitchell, 2004). According to a report published by the UK's Department of Trade and Industry, Taiwan was ranked 6th in the 2006 R\&D scoreboard. Second, different from previous studies, which generally use samples from advanced Western economies, which are known as risk-taking societies, emerging countries have lower level of risk-taking behavior (Hofstede, 2009), and thus may be less inclined to undertake high risk innovation. As it is expected that an emerging economy will face different conditions than those in more developed countries, Taiwan thus offers us an interesting context in which to test whether the related behavioral theory can be applied more generally.

Moreover, behavioral theory also proposes that whether or not a firm has slack resource is another key factor with regard to innovation activities. However, previous studies have produced ambiguous results on the relationship between slack resources and such activities (Nohria \& Gulati, 1996; Herold, Jayaraman, \& Narayanaswamy, 2006). In this paper, we argue that these conflicting results may stem from the impact of different types of slack resources. Specifically, we predict that firms will increase $R \& D$ investment when they have unabsorbed slack resources. In contrast, when they have absorbed slack resources, they are likely to reduce $R \& D$ investment.

In addition to the above predictions, we also argue that a firm's innovation behavior in response to performance feedback and slack resources is likely to be affected by whether a firm belongs to a business group (BG) or not. Prior studies have found that BGs are very common in emerging economies (Granovetter, 1995), such as Taiwan and South Korea. However, the possible different responses to performance feedback and slack resources at BG-affiliated and unaffiliated firms have not been investigated by earlier studies. Drawing on institutional logic, we hypothesize that BG-affiliated firms have a greater inclination to invest in R\&D than unaffiliated ones when faced with discrepancies in performance and when they have slack resources available.

Using panel data covering 274 Taiwanese electronics firms listed on the Taiwan Stock Exchange over the period 1999-2008, we find empirical support for all our theoretical predictions.

We believe that our findings contribute to the innovation literature in three ways. First, our findings extend current understanding of the relationship between performance feedback and R\&D investment in an emerging economy, Taiwan. Second, slack resources are not only beneficial to innovation activities, as previous studies have already found, but also have a negative impact on $\mathrm{R} \& \mathrm{D}$ investment, which earlier studies did not comprehensively examine. Third, our findings extend the previous empirical literature by using a longitudinal data set, and examining firms in a newly industrialized economy, namely Taiwan, with a specific focus on BGs, a very common form of enterprise in such economies. 


\section{THEORY AND HYPOTHESES}

Cyert and March (1963) proposed the behavioral theory to explain the determinant of organizational search behavior, providing a context to consider what makes organizations change their status quo, and in what situations they are willing to take high risks for innovation. They indicated that firms are more likely to change their strategy and take high risks when they are either facing problems or are having an excess of resources. In terms of the problem driven perspective, when an organization's performance does not reach the minimal level that would be regarded as satisfactory by the decision makers, it will extend its search scope until current performance improves (Ahuja \& Katila, 2004). In contrast to problem-driven search, the other perspective concerns firms with a significant level of slack resources, such as cash in hand, which stimulates them to seek opportunities and take higher risks (Greve, 2007). We then elaborate on the relationship between two different search types and $\mathrm{R} \& \mathrm{D}$ investment, as follows.

\section{Performance feedback and R\&D investment}

Building upon Cyert and March's (1963) behavioral theory perspective, organizations are seen as goal-directed systems with bounded rationality that are history dependent and use simple decision rules to adapt their behavior. In the central assumptions of behavioral theory, one of the simple decision rules to measure performance is a comparison with the aspiration level. The aspiration level is a target set by decision makers who use it to evaluate organizational performance. Therefore, a firm's actual performance relative to the aspiration level affects decision makers' inclination to take risks and make changes to their practices (Audia \& Greve, 2006). This difference between actual performance and aspiration is also referred to an 'attainment discrepancy' (Iyer \& Miller, 2008).

Problematic search refers to searches that will be activated when a firm's actual performance is below its aspiration level (negative attainment discrepancy), making change in current strategies more likely (Argote \& Greve, 2007). Donaldson (1999) stated that when performance falls below aspirations it is a signal that reveals maladaptation and dysfunction within the organization, thus motivating firms to reassess their corporate strategy. Such firms will then attempt to undertake remedial actions to enhance their performance until their aspirations are achieved (Cyert \& March, 1963; Greve, 1998). Based on the above arguments, we propose that when a firm has a negative attainment discrepancy, it will make more effort and utilize more resources to ameliorate this negative attainment discrepancy, particularly with regard to its R\&D investment.

Moreover, when a firm's performance is above its aspiration level (positive attainment discrepancy), this may also trigger a firm to initiate search-related activities. In this work we argue that positive attainment discrepancy provides an incentive to seek new technology and loosen controls, thus allowing for greater experimentation and the undertaking of more projects and innovations (Kahneman \& Tversky, 1979). In the specific context of Taiwan's electronic industry, most firms have completely established robust and competitive advantage turnkey systems, with many of their products being consumer devices. One of characteristics of such devices is their short product life-cycle, and thus there is a need to persistently innovate and develop the next generation of products. Most integrated device manufacturers, such as IBM, AMD and Intel, outsource certain functions, such as Fab manufacturing (to firms like Taiwan Semiconductor Manufacturing Company), ${ }^{1}$ assembly (Advanced Semiconductor Engineering), ${ }^{2}$ and testing (King Yuan Electronic Corporation $)^{3}$ to Taiwanese electronic firms. In order to win contracts, these Taiwanese companies

\footnotetext{
1 Taiwan Semiconductor Manufacturing Company is a leading semiconductor manufacturing companies, which had more than $50 \%$ of the global integrated circuit market in 2009 .

2 Advanced Semiconductor Engineering is the number one integrated circuit assembly company in the world.

3 King Yuan Electronic Corporation is the number one integrated circuit testing company in the world.
} 
have to undertake persistent $\mathrm{R} \& \mathrm{D}$ investments in order to have the right abilities and meet the required quality and costing standards (Rice, Liao, Martin, \& Galvin, 2012). Thus, when performance is above the aspiration level, it provides support for a firm to engage in more R\&D activities. Based on these arguments, we present our first hypothesis as follows:

Hypothesis 1: A firm will increase $\mathrm{R} \& \mathrm{D}$ investment when it has an attainment discrepancy between actual performance and its aspiration level.

As stated above, we propose that when a firm has an attainment discrepancy in performance, it will increase its $R \& D$ investment. However, if a firm faces difficulties and is then unable to improve its performance, then decision makers may shift the focus of their attention with their main aim being simply to avoid bankruptcy. Once a firm enters a bankruptcy crisis, the first priority is survival, and thus decision makers shift their focus from aspirations to simply remaining in business (Ocasio, 1997). Such situations can cause considerable anxiety for managers (March \& Shapira, 1992; Audia \& Greve, 2006). With regard to this anxiety, Gilson $(1989,1990)$ examined bankrupt companies and found that $52 \%$ of CEOs, presidents, and board chairpersons lost their positions and were not recruited in another exchange-listed firm for at least 3 years after the bankruptcy; that 44\% of incumbent directors lost their positions on the boards; and that directors who come from bankrupt firms hold fewer seats on other boards after they leave the distressed company. Therefore, in order to protect their reputation and prevent the firm from falling into bankruptcy, decision makers may implement a number of strategies, such as terminating innovation projects (Dougherty \& Bowman, 1995), preventing new activities (Staw, Sandelands, \& Dutton, 1981), and even laying off employees (Love \& Nohria, 2005). Thus, based on these arguments, we present our second hypothesis as follows:

Hypothesis 2: A firm will decrease its R\&D investment when it is threatened by bankruptcy.

\section{Slack search and R\&D investment}

Organizational slack represents potentially utilizable resources and excess inputs, such as underused capacity, facilities, or labor, and financial reserves that can be redeployed to achieve the firms' goals (Daniel, Lohrke, Fornaciari, \& Turner, 2004). Bourgeois (1981) stated that organizational slack is a cushion of actual or potential resources which facilitates $R \& D$ projects and encourages experimentation and exploration. Such slack also allows organizations to successfully adapt and adjust strategies to better deal with internal pressures and external changes. Firms can invest slack resources and create a stock of unused capacity as a buffer against future uncertainty (Tan \& Peng, 2003). Previous studies suggested the following benefits of slack: as a facilitator of strategic behavior, providing sufficient backup to permit the exploration of new product innovation (Damanpour, 1991), seeking new opportunities and entering new markets (Moses, 1992). In addition, abundant slack also alleviates conflicts (Pitelis, 2007) and resolves resource allocation problems in innovation projects (Greve, 2003). Moreover, without adequate slack organizations may suffer from an inability to respond to environmental threats (Voss, Sirdeshmukh, \& Voss, 2008), resulting in elimination of attempts to develop new strategies (D’Aveni, 1989).

However, the empirical results are inconclusive with regard to the effect of organizational slack and innovation. Based on the resource-based view (Barney, 1991), proponents of slack argue that it plays a vital role which allows organizations to pursue innovation and experiment with innovative projects in a resource-constrained environment (Damanpour, 1987). However, opponents draw on agency theory and argue that slack lessens the incentives to innovate and promotes misguided R\&D investments that rarely yield economic benefits (Jensen, 1993), and may result in agents pursuing 
their own interests rather than acting in the interests of the organization (Jensen \& Meckling, 1976). Nohria and Gulati (1996) used a self-report questionnaire answered by department managers at the national subsidiaries of two major European and Japanese multinational corporations. Their finding suggested that the relationship between slack resources and innovation has an inverse $U$ shape. Reviewing the various conflicting results, we contend that these may stem from the relative neglect of two distinct aspects of organizational slack, namely unabsorbed and absorbed slack (Bourgeois, 1981; Peng, Li, Xie, \& Su, 2010). Unabsorbed slack refers to resources that are not yet assimilated into the organization and have a high level of discretion, such as cash in hand and reserve funds. In contrast, absorbed slack consists of resources that are already embedded into an organizational system, as excess costs, but which can be recovered through increased efficiencies over time (Herold, Jayaraman, \& Narayanaswamy, 2006). Although unabsorbed and absorbed slack may have different implications for $\mathrm{R} \& \mathrm{D}$ investment, little research has been conducted into their different effects, and more work is thus obviously required to clarify the relationship between slack search and innovation (Singh, 1986; Sharfman, Wolf, Chase, \& Tansik, 1988; Cyert \& March, 1992; Nohria \& Gulati, 1996).

\section{Different types of slack and R\&D investment}

Unabsorbed slack refers to resources which have a high level of discretion and currently uncommitted resources that are more easily redeployed elsewhere. According to behavioral theory, firms reserve such resources in order to protect their core technology from internal changes and external competition. Unabsorbed slack also acts as a buffer that can assimilate environmental variation and eliminate conflicts among political coalitions in organizations (Cyert \& March, 1963). Because unabsorbed slack is more flexible and more easily reallocated, previous research showed that unabsorbed slack allows organizations to pursue innovative projects, because it provides a cushion against the uncertain returns of such actions (Nohria \& Gulati, 1996) and can increase firm performance (Daniel et al., 2004). Moreover, most developing countries suffer from strong product market competition and a shortage of financial resources, as due to their relative weak financial infrastructures, it is often difficult to raise funds from capital markets (Chung \& Luo, 2008). Therefore, firms endowed with unabsorbed slack have greater resource capacity and flexibility with regard to seeking new opportunities that may lead to more R\&D investment. Based on the above arguments, we present our hypothesis as follows:

Hypothesis 3a: A firm will increase its $\mathrm{R} \& \mathrm{D}$ investment as unabsorbed slack increases.

In contrast to unabsorbed slack, absorbed slack is already tied up in an organization's current operations such as less flexible machine capacity and under-utilized capacity, and requires some time and effort before it can be directly utilized (Bourgeois \& Singh, 1983), making it relatively difficult to identify. Therefore, absorbed slack is synonymous with managerial inefficiency and resource waste rather than with buffers (Jensen \& Meckling, 1976). Tan and Peng (2003) found that absorbed slack has negatively effects on firms' performance, which significantly supports the agency theory perspective that managers may use slack to engage in excessive diversification, empire-building, and pursuing their own interests. In general, $\mathrm{R} \& \mathrm{D}$ investment is a high risk activity with uncertain payback, and managers (agents) may not align their preferences with those of the principals, and when an $R \& D$ activity fails this it may hurt managers' prestige and job security. Absorbed slack thus provide an inducement for managers to pursue their own interests rather than organizational goals, because it is embedded in firms' daily operations and under their direct command.

Furthermore, in resource-based view, when resources are constrained firms that can leverage them more efficiently should perform better than those that cannot (Barney, 1991). In transition economies, such as Taiwan, we take two largely absorbed slacks as examples, excess personnel and 
under-utilized facilities. Excess personnel are an ideal example of absorbed slack, because they may be excess but are also embedded in the organization through allocation to specific routines and tasks (Love \& Nohria, 2005). In addition, each person has specific skills, and cannot easily be redeployed to other department. Once a firm aims to reduce such slack by engage in a round of lay-offs, it may take a considerable amount of time to decide which staff should be removed, and the process itself is likely to evoke strong emotions, cause conflicts and disruptive and have various negative consequences (Herold, Jayaraman, \& Narayanaswamy, 2006). Thus, initially firms may select an alternative approach, such as cutting the R\&D budget and attempting cost reductions instead of lay-offs. There is a common phenomenon in Taiwan that when firms need to transform absorbed slack into unabsorbed slack, they may first choose to cancel innovation projects (including R\&D spending) and then use rotation and shorter working hours to move excess personnel to other tasks.

Moreover, the market position of most Taiwanese electronic firms is in the middle or bottom of the whole value chain (Amsden \& Chu, 2003), and how to manage resources and create maximum efficiency is their primary goal and competitive advantage. When firms have underused facilities, they will reallocate their product lines' capacity and transfer excess capacity to underused facilities. Take Taiwan Semiconductor Manufacturing Company, the number one Fab manufacturing factory in the world as an example, when they have excess 90 nano Fab manufacturing orders that are over their currently capacity, they will transfer the excess capacity into underused facilities by resetting the machines' parameters and then these underused facilities will start to produce and absorb excess capacity. Pursuing maximum productivity efficiently is good for firm performance, but may not beneficial for R\&D investment, because there are no idle facilities and R\&D engineers to experiment on $R \& D$ projects. In order to chase more efficient production they will have to sacrifice $R \& D$ investment. Therefore, firms with a high level of absorbed slack will become cumbersome and can not easily redeploy their low discretionary resources to respond to internal changes and external competition, and this will also harm R\&D investment. Based on these arguments, we present the following hypothesis:

Hypothesis 3b: A firm will decrease its R\&D investment as absorbed slack increases.

\section{Institutional logic in emerging economies}

Furthermore, our research addresses an emerging economy, while most examples of similar studies in the literature use a more developed, Western context, and thus the different business characteristics that apply in these two situations cannot be ignored. An increasing number of scholars (Granovetter, 1995; Chang, Chung, \& Mahmood, 2006; Khanna \& Yafeh, 2007) have found that BGs are significant players in many economies around the world, especially in developing countries. BGs make up an interfirm network which provides internal capital and are sets of legally independent companies that work under common operating and financial controls (Khanna \& Rivkin, 2001).

In Taiwan for an example, BGs have long been a prominent part of the economy, such as the Far Eastern, Formosa, and Tatung groups (see Table 1). Because of the different decision processes that occur in BG-affiliated and unaffiliated firms (Vissa, Greve, \& Chen, 2010), we thus expect that there should exist entirely heterogeneity search behaviors with regard to their R\&D investments. In this work we thus further investigate how BG-affiliated and unaffiliated firms behave with regard to problematic and slack search in the context of an emerging economy. Firms in emerging economies face a number of environmental weaknesses, such as consumers with lower incomes, slower product diffusion and a lack of external capital (Vissa, Greve, \& Chen, 2010). R\&D spending is one way to overcome this difficult environment, as it can enable firms to establish a core competitive advantage (Mahmood \& Mitchell, 2004). Firms can use R\&D activities to solve performance problems which 
Table 1. Description of top 100 Taiwanese Business Groups from 1998 to 2003

\begin{tabular}{lcccccc}
\hline \hline Year & 1998 & 1999 & 2000 & 2001 & 2002 & 2003 \\
\hline $\begin{array}{l}\text { Total number of employees in top 100 Taiwanese } \\
\text { Business Groups (thousand people) (A) }\end{array}$ & 770 & 855 & 898 & 861 & 894 & 1,190 \\
$\begin{array}{l}\text { Total number of employed population in Taiwan } \\
\text { (thousand people) (B) }\end{array}$ & 9,289 & 9,498 & 9,784 & 9,383 & 9,450 & 9,570 \\
$\begin{array}{l}\text { (A)/(B) \% } \\
\text { Sales of top 100 groups aggregated (billion }\end{array}$ & 8.29 & 9.00 & 9.18 & 9.18 & 9.46 & 12.43 \\
$\quad \begin{array}{l}\text { Taiwanese dollars) (C) } \\
\text { National Gross National Product (GNP) (billion }\end{array}$ & 8,854 & 6,604 & 8,343 & 8,151 & 8,587 & 10,048 \\
$\quad \begin{array}{l}\text { Taiwanese dollars) (D) } \\
\text { (C)/(D) \% }\end{array}$ & 55.60 & 70.41 & 85.11 & 84.05 & 85.84 & 98.65 \\
Number of observed groups & 100 & 100 & 100 & 100 & 100 & 100 \\
\hline \hline
\end{tabular}

Note. Data Source: Business Group in Taiwan directory.

stem from outdated processes or obsolete product lines, upgrading their technology and product portfolios. When faced with poor performance feedback, BGs have more ability and inclination to access resources that would be unavailable to unaffiliated firms. One common practice in BGs is tunneling, which refers to the core (parent) companies transferring resources (such as financial and human) to member firms, while the member firms also pool their resources to undertake group strategies and cross-subsidize each other in times of financial distress (Khanna \& Rivkin, 2006). In addition, BG may be better positioned to acquire the capabilities it needs because of its economies of scale, which can lower the average costs of implementing R\&D projects over a large base of operations (Mahmood, Zhu, \& Zajac, 2011). Therefore, BG-affiliated firms have more resources and a higher liquidity than unaffiliated ones, and have a greater inclination and ability to invest in R\&D when they face discrepancies in performance.

Furthermore, while the R\&D investment of unaffiliated firms may result in greater risk and more uncertain payback, it is still difficult for them to abandon an innovation strategy when facing poor performance feedback (Vissa, Greve, \& Chen, 2010), and this is especially true in high knowledge density and innovative-based companies. Thus, when facing a negative attainment discrepancy, unaffiliated firms also tend to invest more in $R \& D$ spending to safeguard their core competitive advantage and make the processes more efficient even borrow money to launch R\&D projects (David, O'Brien, \& Yoshikawa, 2008) in order to survive. However, when facing a positive attainment discrepancy in performance, unaffiliated firms may become cautious about allocating their resources to pursue risky innovation activities (Greve, 2011), and thus companies may assign them to other projects, such as enhancing productivity. Therefore, we propose that both BG-affiliated and unaffiliated firms are sensitive to negative attainment discrepancies in performance, and will increase R\&D investment in such cases, but only BG-affiliated firms have more inclination to increase $R \& D$ investment when performance is above aspiration level. Based on above arguments, we present our next hypothesis, as follows.

Hypothesis 4a: Both BG-affiliated and unaffiliated firms will increase R\&D investment when they have a negative attainment discrepancy in performance. However, only BG-affiliated firms have more inclination to increase R\&D investment when performance is above aspiration level.

Moreover, since there are less external sources of capital in emerging economies, BGs play a critical role in acting as internal markets (Hoskisson, Cannella, Tihanyl, \& Faraci, 2004), and group affiliates 
rely heavily on using intragroup capital market to invest in innovative activities, and benefit from the BGs' reputation and resources that attract foreign technology providers (Luo \& Chung, 2005), as well as a level of concentrated ownership that provides long-term perspectives on R\&D investments (Kim, Kim, \& Lee, 2008). For instance, in South Korea BGs may be able to provide more to affiliated members that are unavailable to independent firms (Kang, 1996). In contrast, unaffiliated firms tend to be more conservative than BGs with regard to R\&D investments when they possess slack resources and are more likely to distribute such resources to other projects, such as market share expansion and increasing efficiency, because these have more stable and predictable outcomes. Based on the characteristics of different types of slack, as discussed earlier, we focus only on unabsorbed slack, in which a high of discretion can be observed between BG-affiliated and unaffiliated firms. Based on these arguments, we present the following hypothesis:

Hypothesis 4b: BG-affiliated firms have more inclination to increase R\&D investment than unaffiliated firms when they possess unabsorbed slack.

\section{METHODS}

\section{Sample and data collection}

Our research sample was drawn from the population of $R \& D$ intensive companies which were publicly listed on the Taiwan Stock Exchange from 1999 to 2008. Taiwan's electronic industry represents an interesting context for this study for the following reasons. First, Taiwan's electronic firms demonstrate a high level of innovation-intensity that makes them a good sample with which to analyze the effects of R\&D investment. Second, in order to help Taiwanese firms move from simple and labor-intensive products to more complex ones, the government has actively promoted the development of Taiwan's technology sector, such as by setting up science parks (Chang, Chung, \& Mahmood, 2006) and acting as a venture capitalist (Amsden \& Chu, 2003) to assist new high-tech companies. Third, the top twenty IPO purchasing companies accounted for $97 \%$ and the top five (HP, Dell, Sony, Apple, and IBM) accounted for $72 \%$ of total IT sector purchasing in Taiwan in 2005 (Kang, Mahoney, \& Tan, 2009).

The details of our sample firms are given in Table 2 and our major data source was the Taiwan Economic Journal database, which includes all the publicly listed company profiles, financial data and so on. To distinguish whether the firms belonged to BGs or not, we collected data for BGs in the Business Groups in Taiwan directory which is a widely used and reliable data source for academic research (Chung, 2001; Khanna \& Rivkin, 2001; Mahmood, Zhu, \& Zajac, 2011) compiled by the China Credit Information Service in Taipei. China Credit Information Service is the

TABle 2. SAMple fiRms by EACH IndUStRY

\begin{tabular}{lcr}
\hline \hline Industry & Number of sample firms & Percentage of sample firms \\
\hline Electronic parts and composition & 78 & 28.47 \\
Semiconductor & 60 & 21.90 \\
Optoelectronic & 57 & 20.80 \\
Computer system and peripheral & 55 & 20.07 \\
Electronic products and distribution system & 24 & 8.76 \\
Total & 274 & 100.00 \\
\end{tabular}


most comprehensive and most prestigious credit checking agency in Taiwan and an affiliate of Standard \& Poor's. The Business Groups in Taiwan data set uses the following objective criteria in identifying BGs as: (1) more than 51\% of the ownership was native capital (2) the group has three or more independent firms, (3) total group sales are more than NT\$400 million (based on the 1984 edition of the Business Groups in Taiwan directory), and (4) the core (parent) firm of the group is registered in Taiwan. Moreover, two sets of data are used in order to better observe volatile events, such as changes in R\&D investment (Lie, 2005), we collected our data twice a year from 1998 to 2007 for the independent variables, with a 1 year lag for the dependent variable. A total of 274 firms and 4,682 observations are included in our sample.

\section{MEASURES}

\section{Dependent variable: $R \& D$ investment}

$\mathrm{R} \& \mathrm{D}$ spending as a percentage of total sales is widely used as a common proxy for innovation (Kim, $\mathrm{Kim}, \&$ Lee, 2008). However, previous research also found that using the ratio of R\&D expenditure to total sales may lead to distortions, such as accounting manipulation (Scherer, 1984). Thus, to test our hypotheses more accurately, we adopted the suggestion of prior studies to use R\&D spending per employee as a proxy variable, which is more stable and less sensitive to the spurious effects of the business cycle (Hill \& Snell, 1988; Baysinger, Kosnik, \& Turk, 1991).

\section{Independent variables}

\section{Attainment discrepancy}

Attainment discrepancy is defined as a firm's actual performance minus its aspiration level, and thus, a positive attainment discrepancy refers to a difference between a firm's actual performance and its aspiration level that is equal to or above zero, while a negative attainment discrepancy refers to a difference between these that is less than zero (Harris \& Bromiley, 2007). In our study, we chose ROA (return on assets) as the performance proxy, as this is the most widely used and stable measurement in the literature (Chen \& Miller, 2007).

Based on Cyert and March (1963) aspiration formation is modeled as including two different proxies, one of which is a firm's own past performance (historical performance) and the other is this performance compared with reference firms in the same industry (social aspiration), such as the average industry-wide performance. In this work, we adopted a comparative approach which was suggested by prior studies (Wiseman \& Catanach, 1997; Park, 2007). That is, if a firm performs under its industry's average level, then its aspiration will be the industry average. In contrast, if a firm performs over its industry's average, then the aspiration level will be 1.05 times historical performance. This measurement is both reasonable and conforms to the relevant theoretical propositions. Specifically, when a firm's performance is below its industry's average, it will aspire to this average, and when a firm achieves this, it will aspire to do better in order to strengthen its current position. Thus, the formula is:

$$
\text { Aspiration }_{i, t}=I\left(P_{i, t}<\mathrm{SA}_{i, t}\right) \times \mathrm{SA}_{i, t}+I\left(P_{i, t} \geq \mathrm{SA}_{i, t}\right) \times 1.05 \times \mathrm{HA}_{i, t-1}
$$

In which $I(\cdot)$ is an index function for which the value is 1 if the statement is true, and 0 otherwise. Aspiration $_{i, t}$ represents the aspiration level of firm $i$ at time $t . P_{i, t}$ is the firm performance of firm $i$ at time $t . \mathrm{SA}_{i, t}$ refers to social aspiration, which is defined as the average performance of other firms (excluding the focal firm) in the same industry. $\mathrm{HA}_{i, t-1}$ refers to historical aspiration, which is defined as the performance of firm $i$ at time $t-1$. 


\section{Distance from bankruptcy}

We adopted Altman's (1983) Z-score as our proxy variable which is a widely used indicator to evaluate how far a firm is from bankruptcy (Fisher, Lee, \& Johns, 2004; Bradley, Aldrich, Shephred, $\&$ Wiklund, 2011), with a lower $Z$ value indicating that a company is closer to bankruptcy. Altman's $Z$-score is calculated based on a firm's accounting information, as follows: $(1.2 \times$ working capital divided by total assets $)+(1.4 \times$ retained earnings divided by total assets $)+(3.3 \times$ income before interest expense and taxes divided by total assets $)+(0.6 \times$ market value of equity divided by total liability $)+(1.0 \times$ sales divided by total assets $)$.

\section{Organizational slack}

Prior researchers have proposed a variety of approaches to measure organizational slack by using accounting data (Bromiley, 1991; Cheng \& Kesner, 1997). In our study, we chose reserve funds as the unabsorbed slack proxy variable, as they are the most liquid resources for managers to utilize. The proxy variable for absorbed slack is the inventory ratio which has little alternative use, calculated by an organization's inventory funds divided by sales (Bourgeois \& Singh, 1983; Miller \& Leiblein, 1996; Tan \& Peng, 2003).

\section{BG-affiliated and unaffiliated firms}

The Business Groups in Taiwan data set provides a list of BGs and also gives the related figures for each group. We coded and categorized the firms by reading all the relevant figures and annual reports, and then separated our observations into BG-affiliated and unaffiliated firms.

\section{Control variables}

Our study controls several firm- and industry-level variables that may affect R\&D investment. Three firm-level control variables are firm age, firm size and growth in firm operating profit. Firm age may affect innovation due to accumulating experience (Huergo \& Jaumandreu, 2004). We measured age as the difference between the year when the firm was observed in our sample and the year when it was established. Firm size is the second control variable (He \& Wong, 2004), as large firms may also have the benefit of economies of scale and access to more resources to undertake innovative activities. We captured total assets as our proxy variable to measure firm size. The third firm-level control variable is growth in operating profit, as a firm's operating capability may also influence future R\&D spending. Moreover, the three industry-level control variables used are industry average R\&D intensity, industry sales growth and industrial competitiveness. We categorized the sample into five industries, as shown in Table 2, based on the Standard of Industry Classification in Taiwan, and then calculated the average $R \& D$ intensity ( $R \& D$ expenditure divided by total sales) in each industry. As industry expectations could influence a firm's investment decisions, we also included industry average sales growth as a control variable. The third industry-level control variable is industry competitiveness, which is measured by the Herfindahl-Hirschman Index based on total sales. The Herfindahl-Hirschman Index measurement is a commonly indicator to test market concentration, and takes into account both the number of participants and market share distribution (Cool, Roller, \& Leleux, 1999). It provides a more sophisticated and rigorous measurement of competition in the industry.

\section{RESULTS}

Because we use cross-sectional and time-series data, using the ordinary least squares method may not appropriate. We thus employed panel methodology to analyze our data, and applied the Hausman 
Table 3. Descriptive statistics and correlations

\begin{tabular}{|c|c|c|c|c|c|c|c|c|c|c|c|c|c|c|c|}
\hline Variables & $n$ & Mean & $S D$ & 1 & 2 & 3 & 4 & 5 & 6 & 7 & 8 & 9 & 10 & 11 & 12 \\
\hline Firm age & 4,682 & 16.138 & 9.281 & & & & & & & & & & & & \\
\hline Firm size & 4,682 & 6.631 & 0.626 & $0.198 *$ & & & & & & & & & & & \\
\hline Firm OP growth & 4,448 & 98.310 & $1,992.840$ & $-0.045^{\star}$ & 0.006 & & & & & & & & & & \\
\hline Industry R\&D intensity & 4,682 & 7.699 & 29.685 & $-0.107 *$ & $-0.087^{\star}$ & 0.005 & & & & & & & & & \\
\hline Industry sales growth & 4,682 & 344.816 & $1,793.367$ & $-0.063^{*}$ & 0.023 & 0.003 & $0.040^{*}$ & & & & & & & & \\
\hline Industry competition & 4,682 & 0.093 & 15.211 & $-0.218^{\star}$ & $0.102^{\star}$ & 0.021 & $0.240^{*}$ & $0.169 *$ & & & & & & & \\
\hline 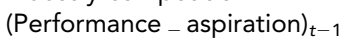 & 4,352 & -2.739 & 0.001 & $-0.066^{*}$ & -0.003 & $0.152^{\star}$ & -0.015 & 0.006 & -0.005 & & & & & & \\
\hline Performance $_{t-1}$ & 4,603 & 8.993 & 9.656 & $-0.098^{\star}$ & -0.015 & $0.098^{*}$ & -0.002 & -0.013 & 0.013 & $0.504^{\star}$ & & & & & \\
\hline Aspiration $_{t-1}$ & 4,352 & 11.935 & 8.054 & $-0.122^{\star}$ & $-0.079 *$ & $-0.032^{\star}$ & $0.040^{*}$ & -0.025 & $0.044^{*}$ & $-0.260^{\star}$ & $0.703^{*}$ & & & & \\
\hline Distance from bankruptcy ${ }_{t-1}$ & 4,465 & 0.047 & 0.349 & $-0.048^{*}$ & $-0.134^{\star}$ & $0.035^{\star}$ & $-0.032^{\star}$ & $-0.064^{\star}$ & $-0.076^{\star}$ & $0.255^{\star}$ & $0.546^{*}$ & $0.391 *$ & & & \\
\hline Unabsorbed slack $_{t-1}$ & 4,682 & $1,164.427$ & $6,269.731$ & $0.034^{*}$ & $0.377^{*}$ & 0.013 & -0.012 & -0.003 & $0.059 *$ & $0.117^{\star}$ & $0.182^{\star}$ & $0.120 *$ & $0.107^{*}$ & & \\
\hline Absorbed slack $_{t-1}$ & 4,682 & 0.379 & 5.714 & $-0.054^{\star}$ & $-0.053^{\star}$ & $-0.068^{\star}$ & $0.036^{*}$ & -0.002 & 0.025 & $-0.061^{\star}$ & $-0.059 *$ & $-0.204^{\star}$ & $-0.032^{\star}$ & -0.009 & \\
\hline R\&D spending $t$ & 4,608 & 259.042 & 338.481 & $-0.174^{\star}$ & $0.144^{\star}$ & 0.003 & 0.008 & -0.011 & $0.239^{*}$ & $-0.076^{\star}$ & $0.124^{\star}$ & $0.203^{*}$ & 0.192 * & $0.129 *$ & -0.012 \\
\hline
\end{tabular}

Note. OP=operating profit.

${ }^{*}$ Correlations with absolute values $>0.03$ are significant at the $p<.05$ level. 
test (Baltagi, 1995: 68) to yield a statistically significant result $(p=.0000)$. This significant $p$-value suggests that using a fixed-effect model was more appropriate than a random-effects specification for these data.

Table 3 shows the descriptive statistics and correlations matrix among the variables. To test for the presence of multicollinearity, we checked the variance inflation factor value. The variance inflation factor analysis reveals that multicollinearity is not an issue because the variance inflation factor values of all independent variables range between 1.03 and 1.44, which is far below the acceptable upper bound of 10 . We also test heteroskedasticity in our variables by following previous research (Rajagopalan \& Prescott, 1990), and the results indicate an absence of heteroskedasticity in the data and thus no need for correction.

Table 4 presents the results for our model by using fixed-effect panel regression. According to the hierarchical regression approach, we include only the control variables and add each variable sequentially by following our hypotheses, as shown in Models 1-7. In Model 1, firm age and firm size have a positive effect on R\&D spending, that is, large and older firms have more capability to invest in $\mathrm{R} \& \mathrm{D}$ than small ones. In Hypothesis 1 , we argued that a firm will increase $\mathrm{R} \& \mathrm{D}$ investment when it has an attainment discrepancy between actual performance and its aspiration level. We follow previous studies to separate attainment discrepancy into two categories, one is performance under the aspiration level (negative attainment discrepancy), and the other is performance above it (positive attainment discrepancy). The coefficient for underperforming firms is negatively associated with R\&D spending in all of our models, and this indicates that the more past performance falls below the aspiration level, the higher the firm's spending on R\&D. Moreover, the coefficient of out-performing firms is positively associated with R\&D spending, implying that the larger the positive attainment discrepancy, the higher the investment in R\&D. Hypothesis 1 is thus supported, consistent with the problematic search argument. Furthermore, in Hypothesis 2 we proposed that firms will decrease their R\&D spending when close to bankruptcy and the results strongly support this argument. The coefficient of the $Z$-score is positively related to $R \& D$ spending, which indicates that when firms are further away from bankruptcy, they have a higher level of R\&D investment. In order to clarify how different types of slack influence R\&D spending, Hypothesis 3a proposed that unabsorbed slack positively affects R\&D spending, while Hypothesis $3 b$ stated that absorbed slack has a negative effect. Our results indicated that unabsorbed slack and absorbed slack have significantly positive and negative effects, respectively and thus Hypothesis $3 \mathrm{a}$ and $3 \mathrm{~b}$ are supported. Furthermore, in order to clarify the relationship between positive performance feedback and slack resources (Greve, 2003), we only presents the effect of slack on R\&D investment in Model 6 and we find the results are consistent with the previous ones. Finally, to further investigate how BG-affiliation influences R\&D investment when a firm has an attainment discrepancy and unabsorbed slack, as examined in Hypotheses $4 \mathrm{a}$ and $4 \mathrm{~b}$, we split our sample into BG-affiliated and unaffiliated firms, and the results are shown in Table 5. The results indicate that both BG-affiliated and unaffiliated firms will increase $R \& D$ investment significantly when facing poor performance. However, only BG-affiliated firms will invest in R\&D when performance is above the aspiration level. That is, BG-affiliated firms have more inclination to invest $\mathrm{R} \& \mathrm{D}$ when they face both positive and negative attainment discrepancies in performance, and Hypothesis $4 \mathrm{a}$ is thus supported. Moreover, Hypothesis $4 \mathrm{~b}$ stated that BG-affiliated firms have more ability to undertake R\&D spending when they possess unabsorbed slack. Our results show that, BG-affiliated firms significantly increase R\&D investment, while there is no effect on R\&D spending for unaffiliated firms when they possess unabsorbed slack. Hypothesis $4 \mathrm{~b}$ is thus supported.

Moreover, we also adopted a robustness check by removing the top 5\% and bottom 5\% in each independent variable. The analyses yielded consistent results, and our findings are compared with those from previous studies and summarized in Table 6. For the details of our results and managerial implications will be further discussed in the following section. 
TABLE 4. Results For FiXed-efFect PANeL REgRESSIONS IN R\&D INVESTMENT

\begin{tabular}{|c|c|c|c|c|c|c|c|}
\hline Independent variables & Model 1 & Model 2 & Model 3 & Model 4 & Model 5 & Model 6 & Model 7 \\
\hline Firm age & $4.4598(1.329)^{\star \star \star}$ & $4.6835(1.322)^{\star \star \star}$ & $8.3853(1.386)^{\star \star \star}$ & $8.3144(1.383)^{\star \star \star}$ & $5.3589(1.389)^{\star \star \star}$ & $3.9181(1.319)^{\star \star}$ & $5.2433(1.386)^{\star \star \star}$ \\
\hline Firm size & $118.3798(14.418)^{\star \star \star}$ & $143.9800(15.129)^{\star \star \star}$ & $102.2607(15.812)^{\star \star \star}$ & $92.0773(15.959)^{\star \star \star}$ & $109.9440(15.588)^{\star \star \star}$ & $98.1506(14.637)^{\star \star \star}$ & $99.3610(15.171)^{\star \star \star}$ \\
\hline Firm operating profit growth & $0.0055(0.001)$ & $0.0020(0.002)$ & $0.0015(0.002)$ & $0.0015(0.002)$ & $0.0013(0.002)$ & $-0.0027(0.001)^{\star}$ & $0.0013(0.002)$ \\
\hline Industry R\&D intensity & $0.0716(0.100)$ & $0.0607(0.101)$ & $-0.0133(0.100)$ & $-0.0127(0.099)$ & $-0.0857(0.100)$ & $0.0185(0.100)$ & $-0.0904(0.099)$ \\
\hline Industry sales growth & $-0.0045(0.001)^{\star \star}$ & $-0.0054(0.001)^{\star \star \star}$ & $-0.0048(0.001)^{\star \star \star}$ & $-0.0046(0.001)^{\star \star \star}$ & $-0.0048(0.001)^{\star \star \star}$ & $-0.0044(0.001)^{\star \star}$ & $-0.0046(0.001)^{\star \star \star}$ \\
\hline Industry competition & $1,407.8360(135.356)^{\star \star \star}$ & $=1,474.5840(135.159)^{\star \star \star \star}$ & $1,333.497(134.848)^{\star \star \star}$ & $1,277.6980(135.193)^{\star \star \star}$ & $1,391.0590(132.760)^{\star \star \star \star}$ & $1,318.2660(134.726)^{\star \star \star}$ & $=1,332.0700(133.037)^{\star \star \star}$ \\
\hline$\left(\right.$ Performance $_{t-1}$ - aspiration $\left._{t-1}\right)<0$ & & $-7.5947(0.622)^{\star \star \star}$ & $-9.3882(0.660)^{\star \star \star}$ & $-9.4544(0.659)^{\star \star \star}$ & $-7.9249(0.662)^{\star \star \star}$ & & $-7.9809(0.661)^{\star \star \star}$ \\
\hline (Performance $_{t-1}$-aspiration $\left.t_{t-1}\right) \geq 0$ & & $5.0778(0.889)^{\star \star \star}$ & $2.7706(0.884)^{\star \star}$ & $2.5969(0.883)^{\star \star}$ & $1.9198(0.873)^{\star}$ & & $1.7321(0.872)^{\star}$ \\
\hline Distance from bankruptcy $y_{t-1}$ & & & $172.7946(11.164)^{\star \star \star}$ & $166.1350(11.249)^{\star \star \star}$ & $119.8152(11.922)^{\star \star \star}$ & & $112.2680(12.004)^{\star \star \star}$ \\
\hline Unabsorbed slack ${ }_{t-1}$ & & & & $0.0026(0.001)^{\star \star \star}$ & & $0.0036(0.001)^{\star \star \star}$ & $0.0028(0.001)^{\star \star \star}$ \\
\hline Absorbed slack ${ }_{t-1}$ & & & & & $-240.7713(21.075)^{\star \star \star}$ & $-91.2325(10.557)^{\star \star \star}$ & $-242.7374(21.025)^{\star \star \star}$ \\
\hline Intercept & $-730.6463(84.472)^{\star \star \star}$ & $-951.3905(89.858)^{\star \star \star}$ & $-728.8830(92.618)^{\star \star \star}$ & $-657.8805(93.914)^{\star \star \star}$ & $-678.4244(91.322)^{\star \star \star}$ & $-563.8657(86.554)^{\star \star \star}$ & $-603.491(92.533)^{\star \star \star}$ \\
\hline Model F & $45.27^{\star \star \star}$ & $44.84^{\star \star \star}$ & $42.49^{\star \star \star}$ & $42.62^{\star \star \star}$ & $43.98^{\star \star \star}$ & $45.30^{\star \star \star}$ & $44.26^{\star \star \star}$ \\
\hline$R^{2}$ & 0.0283 & 0.0461 & 0.0588 & 0.0564 & 0.0889 & 0.0422 & 0.0896 \\
\hline Number of observations & 4,426 & 4,336 & 4,164 & 4,164 & 4,163 & 4,409 & 4,163 \\
\hline
\end{tabular}

Note. Standard errors are in parentheses.

${ }^{\star} p<.05,{ }^{\star \star} p<.01,{ }^{\star \star *} p<.001$. 
Table 5. Results for fiXed-effect panel Regressions in BG-AfFiliated AND UNAFFiliated fiRms in R\&D INVEStMent

\begin{tabular}{|c|c|c|c|c|c|c|c|}
\hline Independent variables & Model 1 & Model 2 & Model 3 & Model 4 & Model 5 & Model 6 & Model 7 \\
\hline \multicolumn{8}{|l|}{ BG-affiliated forms } \\
\hline Firm age & $3.2942(1.769)^{\dagger}$ & $3.5985(1.769)^{\star}$ & $7.2717(1.868)^{\star \star \star}$ & $7.1491(1.864)^{\star \star \star}$ & $4.0409(1.879)^{\star}$ & $2.2068(1.766)$ & $3.8487(1.875)^{\star}$ \\
\hline Firm size & $150.7801(19.796)^{\star \star \star \star}$ & $171.9525(20.746)^{\star \star \star}$ & $123.6077(21.956)^{\star \star \star}$ & $109.8936(22.219)^{\star \star \star \star}$ & $127.0072(21.681)^{\star \star \star}$ & $127.6193(20.296)^{\star \star \star}$ & $112.6249(21.914)^{\star \star \star}$ \\
\hline Firm operating profit growth & $0.0003(0.002)$ & $0.0021(0.002)$ & $0.0011(0.002)$ & $0.0011(0.002)$ & $0.0006(0.002)$ & $-0.0038(0.002)^{\star}$ & $0.0005(0.002)$ \\
\hline Industry R\&D intensity & $0.1306(0.138)$ & $0.1157(0.143)$ & $0.0080(0.140)$ & $0.0062(0.140)$ & $-0.0929(0.142)$ & $0.0457(0.139)$ & $-0.1034(0.142)$ \\
\hline Industry sales growth & $-0.0044(0.002)^{\star}$ & $-0.0047(0.002)^{\star \star}$ & $-0.0043(0.002)^{\star}$ & $-0.0041(0.002)^{\star}$ & $-0.0049(0.002)^{\star \star}$ & $-0.0042(0.002)^{\star}$ & $-0.0047(0.002)^{\star \star}$ \\
\hline Industry competition & $1,643.5870(186.242)^{\star \star \star}$ & $1,670.5770(187.304)$ & $1,602.2440(188.758)$ & $1,525.9770(189.431)$ & $1,642.6860(186.071)$ & $1,588.7680(186.191)$ & $1,561.2130(186.629)^{\star \star \star}$ \\
\hline (Performance $_{t-1}$ - aspiration $\left.{ }_{t-1}\right)<0$ & & $-7.6752(0.855)$ & $-10.2855(0.937)$ & $-10.3705(0.935)^{\star \star \star}$ & $-8.5445(0.945)^{\star \star \star \star}$ & & $-8.6114(0.943)^{\star \star \star \star}$ \\
\hline$\left(\right.$ Performance $_{t-1}$ aspiration $\left._{t-1}\right) \geq 0$ & & $6.6059(1.307)^{\star \star \star}$ & $3.6759(1.3194)^{\star \star}$ & $3.3889(1.318)^{\dagger}$ & $2.5459(1.307)^{\dagger}$ & & $2.2311(1.306)^{\dagger}$ \\
\hline Distance from bankruptcy ${ }_{t-1}$ & & & $174.6302(14.592)^{\star \star \star}$ & $167.2704(14.693)^{\star \star \star \star}$ & $121.4318(15.644)^{\star \star \star \star}$ & & $112.8395(15.745)^{\star \star \star \star}$ \\
\hline Unabsorbed slack t-1 $_{1}$ & & & & $0.0026(0.001)^{\star \star \star \star}$ & & $0.0034(0.001)^{\star \star \star}$ & $0.0028(0.001)^{\star \star \star}$ \\
\hline Absorbed slack $k_{t-1}$ & & & & & $-271.2894(31.444)^{\star \star \star \star}$ & $-94.6768(15.383)^{\star \star \star}$ & $-274.6427(31.360)^{\star \star \star \star}$ \\
\hline Intercept & $-947.1332(120.901)^{\star \star \star}$ & $-1,142.2690(128.019)^{\star \star \star}$ & $-863.4090(133.758)^{\star \star \star}$ & $-765.2208(136.091)^{\star \star \star}$ & $-776.6181(31.444)^{\star \star \star}$ & $-751.7476(125.171)$ & $-671.7826(134.621)^{\star \star \star}$ \\
\hline Model $F$ & $46.76^{\star \star \star}$ & $46.29^{\star \star \star}$ & $40.67^{\star \star \star}$ & $40.95^{\star \star \star}$ & $41.85^{\star \star \star}$ & $46.21^{\star \star \star}$ & $42.19^{\star \star \star}$ \\
\hline$R^{2}$ & 0.0504 & 0.0616 & 0.0966 & 0.0955 & 0.1337 & 0.0709 & 0.1321 \\
\hline Number of observations & 2,810 & 2,755 & 2,623 & 2,623 & 2,622 & 2,799 & 2,622 \\
\hline \multicolumn{8}{|l|}{ Unaffiliated firms } \\
\hline Firm age & $7.0489(1.859)^{\star \star \star}$ & $7.0563(1.809)^{\star \star \star}$ & $10.6234(1.864)^{\star \star \star}$ & $10.4333(1.869)^{\star \star \star}$ & $7.8069(1.852)^{\star \star}$ & $7.6440(1.836)^{\star \star \star}$ & $7.6142(1.857)^{\star \star \star}$ \\
\hline Firm size & $59.8095(19.111)^{\star \star}$ & $89.0390(19.836)^{\star \star \star}$ & $60.3386(20.171)^{\star \star}$ & $70.2575(21.585)^{\star \star \star}$ & $72.7507(19.764)^{\star \star}$ & $42.6646(20.289)^{\star}$ & $82.7779(21.142)^{\star \star \star}$ \\
\hline Firm operating profit growth & $0.0009(0.002)$ & $0.0019(0.002)$ & $0.0023(0.002)$ & $0.0023(0.002)$ & $0.0024(0.002)$ & $0.0006(0.002)$ & $0.0024(0.002)$ \\
\hline Industry R\&D intensity & $-0.0323(0.131)$ & $-0.0357(0.125)$ & $-0.0589(0.124)$ & $-0.0631(0.124)$ & $-0.0888(0.121)$ & $-0.0338(0.128)$ & $-0.0931(0.121)$ \\
\hline Industry sales growth & $-0.0047(0.002)^{\star}$ & $-0.0066(0.002)^{\star \star \star}$ & $-0.0054(0.002)^{\star \star}$ & $-0.0054(0.002)^{\star \star}$ & $-0.0047(0.002)^{\star}$ & $-0.0047(0.002)^{\star}$ & $-0.0047(0.002)^{\star \star}$ \\
\hline Industry competition & $954.304(176.813)^{\star \star \star}$ & $1,099.214(172.357)^{\star \star \star \star}$ & . $843.6779(167.823)^{\star \star \star}$ & $872.1806(169.235)^{\star \star \star}$ & $929.0776(164.285)^{\star \star}$ & $822.2108(175.791)^{\star \star \star \star}$ & $957.9048(165.658)^{\star \star \star}$ \\
\hline (Performance $_{t-1}$ aspiration $\left._{t-1}\right)<0$ & & $-7.5972(0.803)^{\star \star \star}$ & $-7.9588(0.802)^{\star \star \star}$ & $-7.9153(0.803)^{\star \star \star}$ & $-6.9110(0.794)^{\star \star \star}$ & & $-6.8669(0.795)^{\star \star \star}$ \\
\hline (Performance $_{t-1}$ - aspiration $\left.{ }_{t-1}\right) \geq 0$ & & $3.0314(1.036)^{\star \star}$ & $1.5720(0.997)$ & $1.6039(0.997)$ & $1.0499(0.976)$ & & $1.0821(0.976)$ \\
\hline Distance from bankruptcy $y_{t-1}$ & & & $168.1354(16.628)^{\star \star \star}$ & $173.3343(17.106)^{\star \star \star}$ & $110.2886(17.672)^{\star \star \star}$ & & $115.5270(18.099)^{\star \star \star}$ \\
\hline Unabsorbed slack ${ }_{t-1}$ & & & & $-0.0063(0.005)$ & & $0.0037(0.005)$ & $-0.0064(0.005)$ \\
\hline Absorbed slack $t_{t-1}$ & & & & & $-198.2972(23.852)^{\star \star \star \star}$ & $-93.6739(12.884)^{\star \star \star}$ & $-198.3506(23.846)^{\star \star \star}$ \\
\hline Intercept & $-379.156(103.279)^{\star \star \star}$ & $-614.462(109.389)^{\star \star \star}$ & $-490.704(109.669)^{\star \star \star \star}$ & $-550.988(119.204)^{\star \star \star}$ & $-477.289(107.159)^{\star \star}$ & $-251.033(111.645)^{\star}$ & $-538.2076(116.468)^{\star \star \star \star}$ \\
\hline Model F & $37.60^{\star \star \star}$ & $37.33^{\star \star \star}$ & $38.83^{\star \star \star}$ & $38.86^{\star \star \star *}$ & $41.10^{\star \star \star}$ & $38.67^{\star \star \star}$ & $41.14^{\star \star \star}$ \\
\hline$R^{2}$ & 0.0217 & 0.0007 & 0.0001 & 0.0001 & 0.0030 & 0.0133 & 0.0036 \\
\hline Number of observations & 1,616 & 1,581 & 1,541 & 1,541 & 1,541 & 1,610 & 1,541 \\
\hline
\end{tabular}

Note. Standard errors are in parentheses.

$B G=$ business group.

${ }^{\dagger} p<.1,{ }^{\star} p<.05,{ }^{\star \star} p<.01,{ }^{\star \star \star} p<.001$ 
Table 6. Comparison of our study findings vs. Prior findings

\begin{tabular}{|c|c|c|}
\hline Studies & Samples & Key findings \\
\hline Greve (2003) & $\begin{array}{l}\text { Archival data of Japanese shipbuilding } \\
\text { industry with } 185 \text { observations from } \\
1971 \text { to } 1996\end{array}$ & $\begin{array}{l}\text { (1) Performance is above aspiration level will decrease } \\
R \& D \text { investment (2) No significant effect in R\&D } \\
\text { investment when performance is under aspiration } \\
\text { level (3) Only absorbed slack has positive effect on } \\
\text { R\&D investment (4) High performance reduces } \\
\text { innovation more than low performance increase it }\end{array}$ \\
\hline $\begin{array}{l}\text { Chen and Miller } \\
\text { (2007) }\end{array}$ & $\begin{array}{l}\text { Archival data of US publicly traded } \\
\text { manufacturing companies (SIC codes } \\
\text { from } 2,000 \text { to } 3,999 \text { ) with } 35,970 \\
\text { observations from } 1980 \text { to } 2001\end{array}$ & $\begin{array}{l}\text { (1) Performance is under aspiration level will increase } \\
\text { R\&D search (2) Performance that is above the } \\
\text { industry aspiration level will decrease R\&D } \\
\text { searches, but not that which is above the firm's } \\
\text { aspiration level (3) A firm close to bankruptcy will } \\
\text { decrease R\&D search (4) Outperform firms will } \\
\text { increase R\&D search when performance is above } \\
\text { aspiration level }\end{array}$ \\
\hline This study & $\begin{array}{l}\text { Archival data of } 274 \text { Taiwan electronic } \\
\text { firms with } 4,682 \text { observations from } \\
1999 \text { to } 2008\end{array}$ & $\begin{array}{l}\text { (1) Firm will increase R\&D investment when they have } \\
\text { performance attainment discrepancy (performance } \\
\text { is below and above aspiration) (2) A firm close to } \\
\text { bankruptcy will decrease R\&D investment (3) } \\
\text { Unabsorbed slack has positive effect on R\&D } \\
\text { investment (4) Absorbed slack has negative effect } \\
\text { on R\&D investment (5) BG-affiliated and unaffiliated } \\
\text { firms will increase R\&D investment when } \\
\text { performance is under aspiration level (6) BG- } \\
\text { affiliated firms have more inclination to investment } \\
\text { R\&D than unaffiliated firms when performance is } \\
\text { above aspiration level (7) Only BG-affiliated firms' } \\
\text { unabsorbed slack will increase R\&D investment }\end{array}$ \\
\hline
\end{tabular}

Note. SIC $=$ Standard of Industry Classification.

\section{DISCUSSION}

It has been almost 50 years since Cyert and March published their seminal work, A Behavioral Theory of the Firm in 1963, in which they argued that the central indicators that motivate firms to change their behavior are performance relative to aspirations and slack resources, and these have since been widely used to explore a range of organizational behaviors, including overall strategy changes (Audia, Locke, \& Smith, 2000; Park, 2007), risk taking (Deephouse \& Wiseman, 2000), market entry (Wally $\&$ Fong, 2000), and financial misrepresentation (Harris \& Bromiley, 2007). In our study, we extend the earlier research by utilizing performance feedback and slack resources to examine corporate $R \& D$ strategy in an emerging country, Taiwan, and also explore their different effects on BG-affiliated and unaffiliated firms.

The results of our study show that problematic search existed among the Taiwanese electronics companies that we observed over the period 1999-2008, as predicted by behavioral theory. When performance is below the aspiration level, both BG-affiliated and unaffiliated firms will increase R\&D investment. More specifically, most firms perceive this negative performance feedback as a signal that they are facing a crisis, and that significant changes need to be made, this leading to a higher level of R\&D spending.

In contrast, when a firm's performance exceeds the aspiration level, BG-affiliated companies are more likely to invest in R\&D than unaffiliated ones. However, it is possible that this finding may be 
partly skewed by the context of this study, the emerging economy of Taiwan. Despite the rapid growth in competitiveness of the Taiwanese electronics industry in recent years, the majority of cutting-edge electronics technologies continue to originate from more advanced Western economies. Most Taiwanese electronics companies thus rely on their upstream customers to access such technologies (Kang, Mahoney, \& Tan, 2009) and are therefore very sensitive to economic volatility, and inclined to adopt more conservative practices. In addition, BGs are leading economic players in Taiwan, and have dominated the country's economic development (Chung \& Luo, 2008). Therefore, affiliated firms are likely to have access to considerable resources from the parent (core) company, and thus have more ability to invest $\mathrm{R} \& \mathrm{D}$ than unaffiliated firms when their performance exceeds the aspiration level. Moreover, while unaffiliated firms may have a greater incentive to undertake R\&D investment, they may have other priorities plans such as enhancing productivity and making financial investments, when their performance exceeds the aspiration level, and so may not increase their R\&D spending until they have accumulated abundant resources. The above findings demonstrate how sustained empirical studies in an institutional context can yield significant and interesting new findings on a prominent but under-explored phenomenon of interest.

Moreover, we also find that firms tend to decrease R\&D investments as they become closer to bankruptcy. Although innovation is an important activity, and very poorly performing firms might have a strong motivation to increase $\mathrm{R} \& \mathrm{D}$ spending, they generally lack the resources needed to make new investments in this area (Fombrun \& Ginsberg, 1990), and often need to terminate on-going $\mathrm{R} \& \mathrm{D}$ projects in order to survive.

Another novel aspect of this study is its investigation into the relationship between two different types of slack resources and R\&D investment. While prior studies argued on theoretical grounds that different types of slack resources may have different effects, our findings are new and different from these earlier works, which indicated that unabsorbed slack has a direct positive effect on R\&D investment, as predicted by the resourced-based view (Barney, 1991). In contrast, as predicted by agency theory (Jensen, 1993), absorbed slack has a negative impact on R\&D spending. Our findings highlight the fact that future research into the role of slack in company decisions needs consider its specific characteristics.

In order to confirm that our overall results reflect actual managerial practices, we also conducted a tape-recorded interview with a CEO of a leading company in the global semiconductor assembly market. He stated that our findings were both interesting and reflected the reality within his organization. The CEO also stated that performance feedback (positive or negative) is a vital index when making decisions, in particular, with regard to how much resources a firm can invest. Most Taiwanese electronics companies have insufficient resources, and in order to pursue maximum efficiency and produce satisfactory products, it is necessary for them to carefully collect information from the market and their partners when deciding how allocate resources, such as capital, labor, and facilities, to carry out an R\&D strategy. The CEO stated that because efficiency is his firm's core competitive advantage, and he needs to use company resources in the way that will is most likely to win and then retain customer contracts. Moreover, the CEO also agreed that the core company in a BG is likely to assist affiliated companies by supply labor and capital when needed to support $R \& D$ projects, because the firms in such groups have strong interlocked interests with other.

In addition, our study extends the behavioral theory of the firm from the Western context to an emerging economy, Taiwan, and applies it to examine the behaviors of BG-affiliated and unaffiliatedfirms with regard to R\&D investments.

\section{LIMITATION OF THE STUDY}

The results of this study are subject to a number of limitations, which also suggest directions for future research. First, we examined the behavior of Taiwanese electronics companies, and future research can 
examine other sectors or national contexts to see if our findings can be generalized. In particular, it would be interesting to replicate the study in another Asian economy such as South Korea, where BGs are even more important. Second, the use of archival data may ignore some mental factors that exist for decision makers in practice. Although behavioral theory claims that recent performance, historical aspiration level and social aspiration can be used to predict firm behavior, a more fine-grained measurement is still needed. Third, different measurements of slack resources may be associated with different results with regard to $R \& D$ investment, and thus future studies should pay more attention to proxy data selection. Lastly, from our interview data, examining R\&D spending along may not catch the full range of firms' innovation behavior, and we suggest that future studies could supplement R\&D spending with other kinds of data on innovation activities, such as patenting and field survey data.

\section{CONCLUSION}

In summary, this study shows that the corporate $R \& D$ investment is significantly influenced not only by performance feedback, but also by different types of slack resources. Moreover, we extend previous studies to demonstrate that BG affiliated firms have a greater inclination to invest in R\&D than unaffiliated ones when they face attainment discrepancies in performance and possess unabsorbed slack. Our study findings are derived from behavioral theory, which highlights the significant effects of performance feedback. In addition, different from prior research, we find that unabsorbed and absorbed slack have different effects on R\&D investment in an emerging economy, Taiwan and especially on firms that are affiliated with BGs. Last but not least, we believe that this work contributes to Cyert and March's (1963) behavioral theory of the firm by showing that the effects of performance feedback and slack resources on organization behavior may be highly contingent on certain organizational contexts, such as whether or not a firm is affiliated with a BG, an issue that was not comprehensively examined by prior studies.

\section{ACKNOWLEDGMENT}

We are grateful to Wong Poh Kam and Choi Young Rok for their guidance in improving the manuscript and providing valuable suggestions.

\section{References}

Altman, E. I. (1983). Corporate distress: A complete guide to predicting, avoiding, and dealing with bankruptcy. New York, NY: Wiley.

Ahuja, G., \& Katila, R. (2004). Where do resources come from? The role of idiosyncratic situations. Strategic Management Journal, 25, 887-907.

Amsden, A., \& Chu, W. W. (2003). Beyond late development - Taiwan's upgrading policies. Cambridge, MA: MIT Press.

Anderson, P., \& Tushman, M. L. (1990). Technological discontinuities and dominant designs: A cyclical Model of technological change. Administrative Science Quarterly, 35, 604-633.

Argote, L., \& Greve, H. R. (2007). A behavioral theory of the firm - 40 years and counting: Introduction and impact. Organization Science, 18, 337-349.

Audia, P. G., \& Greve, H. R. (2006). Less likely to fail: Low performance, firm size, and factory expansion in the shipbuilding industry. Management Science, 52, 83-94.

Audia, P. G., Locke, E. A., \& Smith, K. G. (2000). The paradox of success: An archival and a laboratory study of strategic persistence following radical environment change. Academy of Management Journal, 43, 837-853.

Baltagi, B. (1995). Econometric analysis of panel data. New York, NY: Wiley.

Barney, J. (1991). Firm resources and sustained competitive advantage. Journal of Management, 17, 99-120. 
Baysinger, B. D., Kosnik, R. D., \& Turk, T. A. (1991). Effects of board and ownership structure on corporate R\&D strategy. Academy of Management Journal, 34, 205-214.

Bourgeois, L. J. (1981). On the measurement of organizational slack. Academy of Management Review, 6, 29-39.

Bourgeois, L. J., \& Singh, J. V. (1983). Organizational slack and political behavior among top management teams. Academy of Management Proceeding, pp., 43-47.

Bradley, S. W., Aldrich, H., Shepherd, D. A., \& Wiklund, J. (2011). Resources, environmental change, and survival: asymmetric paths of young independent and subsidiary organizations. Strategic Management Journal, 32, 486-509.

Bromiley, P. (1991). Testing a causal model of corporate risk taking and performance. Academy of Management Journal, 34, 37-59.

Chang, S. J., Chung, C. N., \& Mahmood, I. P. (2006). When and how does business group affiliation promote firm innovation? A tale of two emerging economies. Organization Science, 17, 637-656.

Chen, W. R., \& Miller, K. D. (2007). Situational and institutional determinants of firms' R\&D search intensity. Strategic Management Journal, 28, 369-381.

Cheng, J. L. C., \& Kesner, I. F. (1997). Organizational slack and response to environmental shifts: The impact of resource allocation patterns. Journal of Management, 23, 1-18.

Chung, C. N. (2001). Markets, culture and institutions: the emergence of large business groups in Taiwan, 1950s-1970s. Journal of Management Studies, 38, 719-745.

Chung, C. N., \& Luo, X. W. (2008). Institutional logics or agency costs: The influence of corporate governance models on business group restructuring in emerging economies. Organization Science, 19, 766-784.

Cool, K., Roller, L. H., \& Leleux, B. (1999). The relative impact of actual and potential rivalry on firm profitability in the pharmaceutical. Strategic Management Journal, 20, 1-14.

Cyert, R. M., \& March, J. G. (1963). A behavioral theory of the firm. Englewood Cliffs, NJ: Prentice-Hall.

Cyert, R. M., \& March, J. G. (1992). A behavioral theory of the firm (2nd ed.). Cambridge, MA: Blackwell Business.

D'Aveni, R. A. (1989). The aftermath of organizational decline: A longitudinal study of the strategic and managerial characteristics of declining firms. Academy of Management Journal, 32, 577-605.

Damanpour, F. (1987). The adoption of technological, administrative, and ancillary innovations: Impact of organizational factors. Journal of Management, 13, 675-688.

Damanpour, F. (1991). Organizational innovation: A meta-analysis of effects of determinants and moderators. Academy of Management Journal, 34, 555-590.

Daniel, F., Lohrke, F. T., Fornaciari, C. J., \& Turner, R. A. Jr. (2004). Slack resources and firm performance: A meta-analysis. Journal of Business Research, 57, 565-574.

David, P., O’Brien, J. P., \& Yoshikawa, T. (2008). The implications of debt heterogeneity for R\&D investment and firm performance. Academy of Management Journal, 51, 165-181.

Deephouse, D. L., \& Wiseman, R. M. (2000). Comparing alternative explanations for accounting risk-return relations. Journal of Economic Behavior \& Organization, 42(4), 463-482.

Donaldson, L. (1999). Performance-driven organizational change: The organizational portfolio. Thousand Oaks, CA: Sage.

Dougherty, D., \& Bowman, E. H. (1995). The effects of organizational downsizing on product innovation. California Management Review, 37, 28-44.

Fisher, G., Lee, J., \& Johns, L. (2004). An exploratory study of company turnaround in Australia and Singapore following the Asia crisis. Asia Pacific Journal of Management, 21(1/2), 149-170.

Fombrun, C. J., \& Ginsberg, A. (1990). Shifting gears: Enabling change in corporate aggressiveness. Strategic Management Journal, 11(4), 297-308.

Gilson, S. C. (1989). Management turnover and financial distress. Journal of Financial Economics, 25, 241-262.

Gilson, S. C. (1990). Bankruptcy, boards, banks, and blockholders: Evidence on changes in corporate ownership and control when firms default. Journal of Financial Economics, 27, 355-387.

Granovetter, M. (1995). Coase revisited: Business groups in the modern economy. Industrial \& Corporate Change, 4(1), 93-130.

Greve, H. R. (1998). Performance, aspirations and risky organizational change. Administrative Science Quarterly, 43, 58-86.

Greve, H. R. (2003). A behavioral theory of R\&D expenditures and innovations: Evidence from shipbuilding. Academy of Management Journal, 46, 685-702. 
Greve, H. R. (2007). Exploration and exploitation in product innovation. Industrial \& Corporate Change, 16, 945-975.

Greve, H. R. (2011). Positional rigidity: Low performance and resource acquisition in large and small firms. Strategic Management Journal, 32, 103-114.

Harris, J., \& Bromiley, P. (2007). Incentives to cheat: The influence of executive compensation and firm performance on financial misrepresentation. Organization Science, 18, 350-367.

He, Z. L., \& Wong, P. K. (2004). Exploration vs. exploitation: An empirical test of the ambidexterity hypothesis. Organization Science, 15, 481-494.

Herold, D. M., Jayaraman, N., \& Narayanaswamy, C. R. (2006). What is the relationship between organizational slack and innovation? Journal of Managerial Issues, 18, 372-392.

Hill, C. W. L., \& Snell, S. A. (1988). External control, corporate strategy, and firm performance in research-intensive industries. Strategic Management Journal, 9, 577-590.

Hofstede, G. (2009). Business goals for a new world order: Beyond growth, greed and quarterly results. Asia Pacific Business Review, 15, 481-488.

Hoskisson, R. E., Cannella, A. A. Jr., Tihanyl, L., \& Faraci, R. (2004). Asset restructuring and business group affiliation in French civil law countries. Strategic Management Journal, 25, 525-539.

Huang, C. C., \& Jiang, P. C. (2012). Exploring the psychological safety of R\&D teams: An empirical analysis in Taiwan. Journal of Management \& Organization, 18(2), 175-192.

Huergo, E., \& Jaumandreu, J. (2004). How does probability of innovation change with firm age? Small Business Economics, 22(3/4), 193-207.

Iyer, D. N., \& Miller, K. D. (2008). Performance feedback slack, and the timing of acquisitions. Academy of Management Journal, 51, 808-822.

Jensen, M. C. (1993). The modern industrial revolution, exit, and the failure of internal control systems. Journal of Finance, 48, 831-880.

Jensen, M. C., \& Meckling, W. H. (1976). Theory of the firm: Managerial behavior, agency costs and ownership structure. Journal of Financial Economics, 3, 305-360.

Kahneman, D., \& Tversky, A. (1979). Prospect theory: An analysis of decision under risk. Econometrica, 47, 263-291.

Kang, M. H. (1996). The Korean Business Conglomerates, Institute of East Asian Studies. Berkeley, CA: University of California.

Kang, M. P., Mahoney, J. T., \& Tan, D. C. (2009). Why firms make unilateral investments specific to other firms: The case of OEM suppliers. Strategic Management Journal, 30, 117-135.

Khanna, T., \& Rivkin, J. W. (2001). Estimating the performance effects of business groups in emerging markets. Strategic Management Journal, 22, 45-74.

Khanna, T., \& Rivkin, J. W. (2006). Interorganizational ties and business group boundaries: Evidence from an emerging economy. Organization Science, 17, 333-352.

Khanna, T., \& Yafeh, Y. (2007). Business groups in emerging markets: Paragons or parasites? Journal of Economic Literature, 45, 331-372.

Kim, H., Kim, H., \& Lee, P. M. (2008). Ownership structure and the relationship between financial slack and R\&D investments: Evidence from Korean firms. Organization Science, 19, 404-418.

Lie, E. (2005). Operating performance following open market share repurchase announcements. Journal of Accounting \& Economics, 39, 411-436.

Love, E. G., \& Nohria, N. (2005). Reducing slack: The performance consequences of downsizing by large industrial firms, 1977-93. Strategic Management Journal, 26, 1087-1108.

Luo, X. W., \& Chung, C. N. (2005). Keeping it all in the family: The role of particularistic relationships in business group performance during institutional transition. Administrative Science Quarterly, 50, 404-439.

Mahmood, I. P., \& Mitchell, W. (2004). Two faces: Effects of business groups on innovation in emerging economies. Management Science, 50, 1348-13651.

Mahmood, I. P., Zhu, H. J., \& Zajac, E. (2011). Where can capabilities come from? Network ties and capability acquisition in business group. Strategic Management Journal, 32, 820-848.

March, J. G., \& Shapira, Z. (1992). Variable risk preferences and the focus of attention. Journal of Risk \& Insurance, 59, 328-328.

McGrath, R. G., \& Nerkar, A. (2004). Real options reasoning and a new look at the R\&D investment strategies of pharmaceutical firms. Strategic Management Journal, 25, 1-21. 
Miller, K. D., \& Leiblein, M. J. (1996). Corporate risk-return relations: Return versus downside risk. Academy of Management Journal, 39, 91-122.

Moses, O. D. (1992). Organizational slack and risk-taking behaviour: Tests of product pricing strategy. Journal of Organizational Change Management, 5(3), 38-54.

Nohria, N., \& Gulati, R. (1996). Is slack good or bad for innovation? Academy of Management Journal, 39, $1245-1264$.

Ocasio, W. (1997). Towards an attention-based view of the firm. Strategic Management Journal, 18, 187-206.

Park, K. M. (2007). Antecedents of convergence and divergence in strategic positioning: The effects of performance and aspiration on the direction of strategic change. Organization Science, 18(3), 386-402.

Peng, M. W., Li, Y., Xie, E., \& Su, Z. (2010). CEO duality, organizational slack, and firm performance in China. Asia Pacific Journal of Management, 27, 611-624.

Pitelis, C. N. (2007). A behavioral resource-based view of the firm: The synergy of Cyert and March (1963) and Penrose (1959). Organization Science, 18, 478-490.

Rajagopalan, N., \& Prescott, J. E. (1990). Determinants of top management compensation: Explaining the impact of economic, behavioral, and strategic constructs and the moderating effects of industry. Journal of Management, 16, $515-538$.

Rice, J., Liao, T. S., Martin, N., \& Galvin, P. (2012). The role of strategic alliances in complementing firm capabilities. Journal of Management \& Organization, 18(6), 858-869.

Rosenkopf, L., \& Nerkar, A. (2001). Beyond local Search: Boundary-spanning, exploration, and impact in the optical disc industry. Strategic Management Journal, 22, 287-306.

Scherer, F. M. (1984). Innovation and growth: Schumpeterian perspectives. Cambridge, MA: MIT Press.

Sharfman, M. P., Wolf, G., Chase, R. B., \& Tansik, D. A. (1988). Antecedents of organizational slack. Academy of Management Review, 13, 601-614.

Singh, J. V. (1986). Performance, slack and risk taking in organization decision making. Academy of Management Journal, 29, 562-585.

Staw, B. M., Sandelands, L. E., \& Dutton, J. E. (1981). Threat-rigidity effects in organizational behavior: A multilevel analysis. Administrative Science Quarterly, 26, 501-524.

Tan, J., \& Peng, M. W. (2003). Organizational slack and firm performance during economic transitions: Two studies from an emerging economy. Strategic Management Journal, 24, 1249-1263.

Vissa, B., Greve, H. R., \& Chen, W. R. (2010). Business group affiliation and firm search behavior in India: Responsiveness and focus of attention. Organization Science, 21, 696-712.

Voss, G. B., Sirdeshmukh, D., \& Voss, Z. G. (2008). The effects of slack resources and environmental threat on product exploration and exploitation. Academy of Management Journal, 51, 147-164.

Wally, S., \& Fong, C. M. (2000). Effects of firm performance, organizational slack and debt on entry timing: A study of ten emerging product markets in USA. Industry \& Innovation, 7, 169-183.

Wiseman, R. M., \& Catanach, J. A. H. (1997). A longitudinal disaggregation of operation risk under changing regulations: Evidence from the savings and loan industry. Academy of Management Journal, 40, 799-830. 